Mariusz Kobek $^{1}$, Zbigniew Jankowski ${ }^{2}$, Czesław Chowaniec ${ }^{1}$, Christian Jabłoński ${ }^{1}$

\title{
Niezwykle rzadki przypadek nowotworu złośliwego - kosmówczaka u 24-letniego mężczyzny - trudności w diagnostyce różnicowej uszkodzeń śródczaszkowych w aspekcie opiniowania sądowo-lekarskiego
}

A unique case of malignant neoplasm - choriocarcinoma in a 24-year-old man difficulties in differential diagnostics of intracranial injuries in the aspect of medicolegal opinion

1 Z Katedry i Zakładu Medycyny Sądowej i Toksykologii Sądowo-Lekarskiej SUM w Katowicach

Kierownik: dr med. C. Chowaniec

2 Z Katedry i Zakładu Medycyny Sądowej GUM w Gdańsku

Kierownik: dr hab. med. Z. Jankowski

Diagnostyka różnicowa zmian chorobowych i urazowych oparta o wyniki badań obrazowych, w szczególnych przypadkach może nastręczać poważne trudności, a nawet być przyczyną błędu medycznego i w konsekwencji wydania nieprawidłowej opinii sądowo-lekarskiej. Przedstawiono niezwykle rzadki przypadek rozsianego nowotworu złośliwego - kosmówczaka u 24-letniego mężczyzny. Kilka dni po tym zdarzeniu został przyjęty do kliniki neurochirurgii z rozpoznanym w badaniu TK głowy pourazowym krwiakiem śródmózgowym z przebiciem do układu komorowego. Po wypisaniu ze szpitala w stanie ogólnym dobrym - mężczyzna po kilkunastu dniach zmarł. Badanie sekcyjne, poszerzone o badanie histopatologiczne, wykazało liczne przerzuty pierwotnego nowotworu jądra, m.in. do mózgu.

Differential diagnostics of pathologic and traumatic lesions based on image techniques may in some cases cause serious difficulties or even be the cause of a medical error resulting in incorrect medicolegal opinion. The authors present a unique case of primary malignant neoplasm of the testicle (choriocarcinoma) in a 24-year-old man. Several days after the event, he was admitted to Department of Neurology with CT-confirmed traumatic intracerebral hematoma communicating with the ventricular system. Discharged in a good general condition, the patient died several days later. A postmortem examination combined with histopathology demonstrated numerous metastases of the primary carcinoma, which also involved the brain, arousing suspicions of head injury in consequence of a crime.

Słowa kluczowe:

kosmówczak, krwiak śródmózgowy, diagnostyka różnicowa

Key words:

choriocarcinoma, intracelebral hematoma, differential diagnosis.

\section{WSTĘP}

Diagnostyka różnicowa zmian chorobowych i urazowych w ośrodkowym układzie nerwowym u osób żywych jest bardzo trudna, często niemożliwa, zarówno przy posługiwaniu się nowoczesnymi metodami radiologicznymi (TK, MRI), jak i w czasie zabiegu neurochirurgicznego. Może to prowadzić do błędnych wniosków, których skutkiem jest sporządzenie nieprawidłowej opinii sądowo-lekarskiej z nieodwracalnymi konsekwencjami prawnymi dla osoby lub osób podejrzanych. 
Dlatego postanowiono przedstawić rzadki, śmiertelny przypadek 24-letniego mężczyzny, z uogólnioną chorobą nowotworową, stanowiącą zejście nabłoniaka kosmówkowego (kosmówczaka) jądra z przerzutem do mózgu, powikłanym krwotokiem do guza, z urazem głowy w wywiadzie.

\section{OPIS PRZYPADKU}

Chory w niejasnych okolicznościach miał doznać urazu głowy w wyniku pobicia. Mężczyzna zeznał, że nie pamiętał dokładnie daty ani godziny zdarzenia. Pamiętał, że został pobity przez kilku nieznanych sobie sprawców. Leżąc na ziemi był prawdopodobnie kopany po głowie. Wg relacji matki pokrzywdzonego jej syn w dniu 20.07.2005 roku wrócił do domu twierdząc, że został pobity przez grupę kilku mężczyzn. Miał otarcia naskórka na prawej kończynie dolnej i ręce. W dniu 24.07. 2005 roku jego ojciec znalazł go nieprzytomnego w łazience, po czym został przewieziony karetką pogotowia do szpitala.

Pokrzywdzony przez 10 dni był hospitalizowany w klinice neurochirurgii. Powodem przyjęcia było zdiagnozowane na podstawie badania TK głowy pourazowe ogniskowo krwotoczne w prawym płacie czołowym z przebiciem do układu komorowego mózgu. Pacjent przy przyjęciu był nieprzytomny, wydolny krążeniowo i oddechowo, stwierdzano objawy ogniskowego uszkodzenia ośrodkowego układu nerwowego. Z obrażeń zewnętrznych opisano drobne otarcie naskórka, obrzęk tkanki podskórnej i zaczerwienienie skóry prawej okolicy czołowo-skroniowej głowy oraz otarcia naskórka na kończynie górnej prawej. Chorego operowano doraźnie, usuwając ognisko krwotoczne z pozostawieniem drenażu zewnętrznego w komorze bocznej prawej. Po leczeniu operacyjnym nastąpiła systematyczna poprawa stanu chorego. Chory przytomny, w pełnym kontakcie słownym, bez objawów ogniskowego uszkodzenia OUN, w stanie ogólnym dobrym został wypisany do domu.

$\mathrm{Na}$ podstawie dokumentacji lekarskiej lekarz biegły sądowy w dniu 10.08.2005 roku sporządził opinię sądowo-lekarską. W opinii odnotował m.in: „pokrzywdzony w wyniku doznanych obrażeń doznał urazu czaszkowo-mózgowego pod postacią krwiaka wewnątrzczaszkowego. Powyższe obrażenia stanowią ciężki uszczerbek na zdrowiu poprzez spowo- dowanie choroby realnie zagrażającej życiu" (zgodnie z obowiązującym w Polsce kodeksem karnym).

Mężczyzna po upływie 1 tygodnia został poddany hospitalizacji w oddziale chirurgicznym z rozpoznaniem: „krwioplucia, rozsianego procesu nowotworowego i niewydolności krążenia". Pomimo zastosowanego tam wielospecjalistycznego leczenia nastąpił zgon chorego.

Wykonane w Zakładzie Medycyny Sądowej w Katowicach oględziny i sekcja zwłok denata wykazały: uogólnioną chorobę nowotworową w postaci przerzutów nowotworu złośliwego w płucach, wątrobie, nerkach i gruczole krokowym oraz małe ognisko krwotoczne w lewym jądrze (budzące podejrzenie pierwotnego ogniska nowotworu), a także wylew krwi do nadnercza lewego. Ponadto stwierdzono stan po niedawno przeprowadzonym zabiegu operacyjnym - kraniotomii prawostronnej i ewakuacji ogniska krwotocznego w prawym płacie czołowym.

Badaniem histopatologicznym stwierdzono: w wycinkach z jądra pierwotny, złośliwy nowotwór nabłoniak kosmówkowy złośliwy (kosmówczak); w wycinkach z płuc, nerki, wątroby, nadnerczy oraz mózgu (w okolicy rany pooperacyjnej i jamy pokrwotocznej) - przerzuty nowotworu.

Ponowna ocena tomogramu komputerowego głowy, wykonanego u pokrzywdzonego w dniu 24.07. 2005 roku na oknie miękkotkankowym i kostnym, dokonana w Zakładzie Medycyny Sądowej w Katowicach wykazała: obraz TK - jak w przypadku świeżego krwiaka śródmózgowego bez widocznych wykładników urazu w tkankach miękkich i w obrębie struktur kostnych.

\section{DYSKUSJA}

W przedstawionym przypadku zwraca uwagę wyraźna niewspółmierność/dysproporcja między obrażeniami zewnętrznymi na skórze głowy a zmianami wewnątrzczaszkowymi, sugerującymi etiologię urazową. Na skórze głowy stwierdzono drobne otarcie naskórka, zaczerwienienie skóry i obrzęk tkanki podskórnej w okolicy czołowo-skroniowej prawej. Badaniem TK, śródoperacyjnie i w czasie sekcji, w mózgu ujawniono ognisko krwotoczne w płacie czołowym prawym, komunikujące z układem komorowym, z powstaniem wtórnego krwiogłowia wewnętrznego. Zarówno wykonane za życia 
badanie TK głowy, jak i badania pośmiertne nie wykazały charakterystycznych zmian urazowych wewnątrzczaszkowych: stłuczenia i/lub rozerwania mózgu oraz krwiaków nadtwardówkowego, podtwardówkowego i podpajęczynówkowego, a także złamań kości czaszki i wylewów w tkance podskórnej oraz w czepcu ścięgnistym [1].

Izolowane ognisko krwotoczne w mózgu o takiej lokalizacji powinno sugerować chorobową etiologię. Może ono stanowić powikłanie pierwotnego guza mózgu, przerzutu nowotworu złośliwego do mózgu z narządów klatki piersiowej bądź jamy brzusznej lub angiopatii kongofilnej (CAA - cerebral amyloid angiopathy). Bardzo rzadko stanowi ono powikłanie anomalii naczyniowych (naczyniaków) bądź zaburzeń krzepnięcia krwi - skazy krwotocznej, najczęściej w przebiegu małopłytkowości. Wymienione zmiany można rozpoznać w czasie badania histopatologicznego [2, 3].

Ognisko krwotoczne w mózgu o takiej lokalizacji nie jest charakterystyczne dla powikłań wewnątrzczaszkowych u osób chorujących na nadciśnienie tętnicze, bowiem w takich przypadkach najczęściej jest ono zlokalizowane w okolicy jąder podstawy [3].

Angiopatia kongofilna występuje u ludzi w podeszłym wieku i charakteryzuje się odkładaniem białka beta-amyloidu (beta-amyloid) w ścianie drobnych tętnic. Jest łatwa do rozpoznania w preparatach histopatologicznych barwionych czerwienią Kongo, daje zieloną fluorescencję w preparatach barwionych thioflawiną S. Można ją także wykryć w barwieniu immunohistochemicznym na A-beta-amyloid [3].

Zaburzenia krzepnięcia krwi, jako przyczynę ogniska krwotocznego, pozwalają wykluczyć wykonane za życia badania koagulologiczne.

W opisywanym przypadku, w czasie badania histopatologicznego wycinków ze ściany jamy po usuniętym w czasie zabiegu neurochirurgicznego ognisku krwotocznym, stwierdzono obecność nabłoniaka kosmówkowego, nowotworu złośliwego, wywodzącego się z wielopotencjalnej komórki płciowej, którego ognisko pierwotne w przedstawionym przypadku było zlokalizowane w jądrze. Jest to nowotwór złośliwy, wykazujący dużą zdolność do naciekania i niszczenia ścian naczyń krwionośnych gospodarza oraz ich wykorzystywania dla swoich potrzeb, ponieważ nie posiada własnych naczyń [4]. Takie zachowanie się nowotworu sprzyja krwotokom do guzów, w tym zlokalizowanych w mózgu, co często jest pierwszym objawem choroby [5]. Czynnikami dodatkowymi, predysponującymi do krwotoku do guza, mogą być: nagły wzrost ciśnienia tętniczego krwi oraz urazy głowy. Często są to urazy głowy działające nawet z niewielką siłą, na które chory i jego otoczenie może nawet nie zwrócić uwagi. W takich przypadkach ognisko kosmówczaka stanowi „locus minoris resistentiae" [6].

W prezentowanym przypadku zmiany urazowe w powłokach głowy w postaci niewielkich otarć naskórka i podbiegnięć krwawych, opisanych w dokumentacji lekarskiej jako zaczerwienienie oraz obrzęk i tkanki podskórnej, przy braku innych, ww. zmian urazowych wewnątrzczaszkowych, wskazują, że uraz głowy godził z małą siłą [6]. W takich przypadkach należy rozważyć dwie sytuacje:

1. uraz głowy, nakładając się na zmiany chorobowe w mózgu, spowodował krwawienie z nacieczonych przez nowotwór naczyń w obrębie guza i powstanie ogniska krwotocznego - z towarzyszącym obrzękiem mózgu;

2. samoistny, nagły krwotok śródmózgowy z nacieczonych przez nowotwór naczyń w obrębie guza, współistniejący z obrzękiem mózgu i zaburzeniami świadomości, powodującymi upadek i uderzenie głową o twarde podłoże.

Dane ze śledztwa, z których wynika, że mężczyzna miał zostać pobity, wskazują na pierwszą sytuację jako bardziej prawdopodobną.

W przypadkach interwencji neurochirurgicznej i ewakuacji ognisk krwotocznych w mózgu konieczne jest badanie histopatologiczne usuniętych skrzepów krwi.

Gdyby w przedstawionym przypadku takie badanie wykonano, to już w czasie pierwszej hospitalizacji można by dojść do wyżej przedstawionych wniosków.

Interpretacja sądowo-lekarska i prawna stwierdzonych zmian urazowych głowy, dokonana przez medyka sądowego w czasie I-szej hospitalizacji chorego, była błędna, bowiem na podstawie dostępnej dokumentacji lekarskiej przyjęto jednoznacznie urazową, nietypową etiologię ogniska krwotocznego w mózgu [6]. 


\section{PIŚMIENNICTWO}

1. Besenki N.: Traumatic injuries: imaging of head injuries. Eur. Radiol. 2002 Jun; 12 (6): 1237-1252. Epub 2002 Apr. 19.

2. Cave W. S.: Acute, nontraumatic subdural hematoma of arterial origin. J. Forensic Sci. 1983 Jul; (3): 786-789.

3. Prayson R. A.: Neuropathology. Elsevier Churchill Livingstone. 2005.

4. Le-Ming Shih, Mazur M. T., Kurman R. J.: Gestational trophoblastic disease and related lesions. In: Blaustein's pathology of the female genital tract. Kurman R. J. Springer-Verlag New York. 2002, 1193-1247.

5. Erten S. F., Ertas E., Duygulu C., Aydin E. N., Colak A.: An unsual presentation of metastatic adenocarcinoma in the cerebellum associated with intratumoral hemorrhage mimicking a stroke. A case report. Neurosurg. Rev. 1998, 21 (1): 69-71.

6. Kidd D., Plant G. T., Scaravilli F., McCartney A. C., Stanford M., Graham E. M.: Metastatic choriocarcinoma presenting as multiple intracerebral haemorrhages; the role of imaging in the elucidation of the pathology. J.Neurol., Neurosurg., Psychiatry. 1998, Dec; 65 (6): 939-941.

Adres do korespondencji: $\mathrm{dr}$ med. Mariusz Kobek Katedra i Zakład Medycyny Sądowej i Toksykologii Sądowo-Lekarskiej SUM w Katowicach ul. Medyków 16 40-752 Katowice tel.: +48502541959 e-mail: mariusz.kobek@wp.pl 